\title{
Myeloid Stem Cell
}

National Cancer Institute

\section{Source}

National Cancer Institute. Myeloid Stem Cell. NCI Thesaurus. Code C158542.

A stem cell derived from the hematopoietic stem cell that generates myeloid cells (granulocyte, erythrocyte, monocyte, megakaryocyte). 